\title{
Education and Non-domination: Reflections from the Radical Tradition
}

\author{
Judith Suissa ${ }^{1}$ \\ Published online: 11 April 2019 \\ (c) The Author(s) 2019
}

\begin{abstract}
This paper explores the implications of a radical republican conception of freedom as nondomination, rooted in the anarchist tradition. In discussing both the non-statist theoretical frameworks and the practical educational experiments associated with this tradition, I suggest that it can add a valuable dimension to recent critical work in philosophy of education that draws on the republican idea of freedom as non-domination.
\end{abstract}

Keywords Republicanism $\cdot$ Freedom $\cdot$ Non-domination $\cdot$ Anarchism $\cdot$ Radical education

\section{Introduction}

A number of recent works in philosophy of education, including some publications in this journal, have drawn on the republican tradition, particularly the republican notion of freedom as non-domination, in defending arguments about education. These arguments address issues of social justice, civic education, selective schooling, critical pedagogy and pupil autonomy, and are often critical of contemporary educational policy and practice. However, while focusing on the idea of freedom as non-domination, the authors of such work generally overlook the arguments of radical republican and anarchist theorists who have developed this idea as part of a radical criticism of capitalism and the state. In failing to engage with this tradition and, connectedly, failing to examine the statist assumptions of their own arguments, these theorists' positions are, I suggest, far less critical of mainstream educational theory, practice and policy than they set out to be. In the following discussion, I explore the implications of the radical republican approach to freedom as non-domination and suggest that taking it seriously may lead us to ask very different, and perhaps fruitful, questions about education.

Judith Suissa

j.suissa@ucl.ac.uk

1 Department of Education, Practice and Society, UCL Institute of Education, University College London, 20 Bedford Way, London WC1H 0AL, UK 


\section{The Revival of the Republican Tradition}

Recent political philosophy has seen a revival of the republican tradition, notably through the work of Philip Pettit and Quentin Skinner. Several contemporary philosophers of education have engaged with this work, whether through a defence of civic virtues (Peterson 2011), as part of a theory of educational justice (Macleod 2015; Peterson 2017; Snir and Eylon 2017); a defence of a more democratically negotiated curriculum (Hopkins 2015) or an account of an education system designed to support republican liberty (Hinchliffe 2015; Snir and Eylon 2016). What these accounts have in common is a focus on the central republican conception of freedom as non-domination, often regarded as constituting the main conceptual distinction between republicanism and liberalism.

As Colin Macleod notes, "In the recent revival of the republican tradition of political theory $[\ldots]$, little attention has been paid to the relation between freedom as non-domination and education "(2015, p. 456). In their work, Itay Snir and Yuval Eylon set out to address this lacuna, claiming that "attempts to develop a republican educational theory are still hesitant, and fail to take the republican radical conception of freedom to its full conclusions" (2016, p. 759).

In a recent paper, Andrew Peterson takes issue with this criticism and extends Snir and Eylon's argument against private schooling to offer a powerful criticism of selective schooling in England, drawing on the republican principle of freedom as non-domination which, as he notes, requires that we attend to the domination of one group of citizens over another (Peterson 2017, p. 171). It is not my intention here to engage with the substantive arguments of these theorists or the debates amongst them. What I propose to do, rather, is to step back and reflect on the ways in which what are essentially political discussions about education-i.e. discussions focused on central political concepts such as justice, freedom and equality - tend to assume as given the contingent political frameworks and institutions within which educational processes take place. Their explorations of the relationship between educational processes and political values, because they do not involve positing the imaginative alternative of radical, non-statist forms of political organization, may therefore be limited in their critical potential, and in the theoretical analysis that they suggest.

While I do not want to dismiss the important work that has been done on issues of educational justice and equality - work that has concrete policy implications for issues such as private and selective schooling, school choice, and the curriculum-I agree with Michael Sandel that doing philosophy means "reflecting critically on the way things are. That includes reflecting critically on social and political and economic arrangements. It always intimates the possibility that things could be other than they are. And better." (in Edmonds and Warburton 2010, xxi).

In embarking on such critical reflection, we need to consider the concepts that we use in the broadest possible sense, as it is surely in doing so that we can both imagine how things could be and argue about how things should be. Theorists who defend a republican concept of freedom as non-domination are presumably concerned to articulate and defend a normative account of a society in which human freedom, so understood, is enhanced and protected. It would therefore seem to follow that a discussion that has as its focus the processes by which children are educated, as part of a concern with human freedom, would address the issue of the social and political structures and institutions within which education takes place. In other words, discussions about freedom in education must involve, at least partly, asking questions about what a free society would look like, what forms of 
education could support and nurture such a society, and whether our current social and political institutions are conducive to this goal; as well as imagining different institutions that would be more conducive to it.

However, none of the theorists mentioned above question either the institution of state schooling or the capitalist state itself as the framework within which their analysis is conducted. There is, however, a rich body of political theory, both within the republican tradition and outside it, that is similarly committed to the central value of freedom as nondomination, but that sees the state, and particularly the capitalist state, as conceptually and historically in tension with this value. In ignoring this tradition, and in failing to acknowledge, much less reflect on, the statist assumptions within their own work and that of the thinkers they invoke, contemporary philosophers of education developing normative arguments about educational policy and practice through the lens of the idea of freedom as nondomination are, I will argue, depriving their readers of an important element in the conceptual toolkit available. I will suggest that, to the extent that critical philosophical work on education, justice, and freedom requires an exercise of the political imagination, imagining a world without the state can add an important dimension to such work.

\section{Freedom as Non-domination}

As Geoffrey Hinchliffe notes (2013), the scholars credited with the revival of the republican tradition within Western political theory, notably Quentin Skinner and J.G.A. Pocock, saw their project as part of a critique of modern liberalism.

Key to this project is a rigorous philosophical analysis, later developed further by Philip Pettit, of the republican concept of freedom as non-domination. Neo-republican political theorists contrast this concept with the liberal view of freedom as non-interference. The example republican theorists are fond of using to illustrate this contrast is that of slavery. Whereas for liberals, people are unfree when they are interfered with, for republicans, a person is unfree if someone has the capacity to arbitrarily interfere with her. As Skinner puts it,

The nerve of republican theory can thus be expressed by saying that it disconnects the presence of unfreedom from the imposition of interference. The lack of freedom suffered by slaves is not basically due to their being constrained or interfered with in the exercise of any of their specific choices. Slaves whose choices happen never to fall out of conformity with the will of their masters may be able to act without the least interference. They may therefore appear, paradoxically, to be in full possession of their freedom, since none of their actions will ever be prevented or penalized. Such slaves nevertheless remain wholly bereft of liberty. They remain subject to the will of their masters, unable to act according to their own independent will at any time. They are, in other words, not agents at all. (Skinner 2008, pp. 89-90).

According to Pettit, freedom as non-domination cannot be categorised as "negative" or "positive" in the sense of Isaiah Berlin's famous distinction-a distinction that Pettit believes "has served us ill in political thought" (Pettit 1997, p. 18) where, at least in the Anglophone tradition, modern political philosophy has been overwhelmingly focused on freedom as non-interference.

This concept of freedom is also central to the work of the philosophers of education who have engaged with the republican tradition. Hinchliffe (2015, p. xiiv) states that his 
aim is "to build on the concept of republican liberty" and "to explore the relation between liberty and education". Similarly, Snir and Eylon (2017, p. 759) see their work as contributing to the project of developing "an educational theory fully committed to the idea of freedom as non-domination". Peterson, whose 2011 work is focused on developing a republican model of civic education, also makes central use of the republican idea of freedom as non-domination.

Hinchliffe's project is not to defend a form of civic education or an account of civic virtues, but to show "how the practice of education can be thought of in a way that would buttress and inform our thinking about liberty." (2015, p 160). He draws on the work of John McDowell and Robert Brandom, particularly the idea of the space of reasons, in order to develop a philosophical account of how education can prepare liberty-bearing persons to live together. Hinchliffe's account is intended to show how education, particularly through knowledge, can empower students so as to enable them to live without domination. In the following discussion I will argue that this critical philosophical analysis can be enriched by considering non-statist traditions as part of the enquiry into questions about the political framework within which people can live together.

\section{The Radical Republican Tradition}

Alex Gourevitch (2013a, 2015) argues that the republican conception of freedom has the potential to recapture the value of freedom from the popular rhetoric of the right, where it is associated with freedom from government intervention. Crucially, "freedom understood as non-domination, or the absence of arbitrary power, captures the experience and injustice of having a master, whether they are a king, a slave-owner, a capitalist, or a patriarch" and "has the ability to criticise a wider set of social relations than narrower conceptions of freedom" (Leipold 2016).

In fact, as several theorists have pointed out (see e.g. Bellamy 2002; Gourevitch 2013b, 2015; Leipold 2013, 2016), there is a radical strand of republican thought that draws on Rousseau's argument that economic equality is essential for freedom. On this view, for a republic to be non-dominating, "no citizen shall ever be wealthy enough to buy another, and none poor enough to be forced to sell himself." (Rousseau 1920, p. 89).

Within this radical republican tradition, the concept of freedom as non-domination is linked to a critique of capitalism: the worker is unfree because she has no choice but to sell her labour to an employer, who effectively becomes her master. Furthermore, this workplace relationship of domination is a consequence of the structural domination created by vastly unequal ownership of the means of production.

The history of this strand of radical republicanism, especially within the nineteenth century American labour movement, has been comprehensively researched by Alex Gourevitch $(2015,2013 a)$. Like the neo-republican thinkers cited above for whom slavery is the paradigmatic example of a relationship of domination, these labour activists drew on the analogy with slavery in defending their political position. Gourevitch quotes from an 1828 speech by William Heighton, a radical shoemaker and founder of the Working Men's Party of Philadelphia. The wage-labour system, Heighton claimed, "is... an iron chain of bondage. A system of unjust abstraction, oppression, and legal fraud, by which the most useful classes of society are drained of their wealth, and consigned over to eternal toil and neverending slavery." (Gourevitch 2015, p. 77). 
As Gourevitch notes (2012), these radical thinkers and activists articulated their criticism of capitalism and wage labour "in the language of the revolutionary republicanism of their forefathers", according to which freedom was a condition of independence. As they saw it, massive inequalities in the control over productive property had made the propertyless dependent upon the owners of property, so that wage-labourers were kept "in a state of humble dependence" that they regarded as a form of slavery. Workers who agreed to a labour contract did so under conditions of dependence as they had no reasonable alternative but to sell their labour. Labour republicans fought to abolish the wage system in favour of cooperative forms of production.

Other theorists have gone so far as to argue that "a consistent republicanism must be anti-capitalist" (Kinna and Pritchard 2012, p. 1), for "if republicans are serious about slavery as a defining feature of non-freedom as domination, the dependencies created by property-relations in capitalism are central to domination and must be recognised by contemporary republicans." (ibid).

Furthermore, Kinna and Pritchard argue (ibid, p. 9), "when neo-republicans look to ground non-domination on anti-slavery, they discuss slavery as a general political principle relating to the relations between citizens and rulers, but generally pay less attention to slaveholders and slaves and, more problematically, to the ways in which modern conceptions of private property are outgrowths of ancient understandings of slavery."

Drawing on both the testimony of slaves and the writings of nineteenth century socialists, Kinna and Pritchard show that for many radical activists and theorists, "abolition of slavery alongside the institutionalisation of wage slavery produced nothing but the institutionalisation of far wider conceptions of who was eligible to have rights by virtue of having newly acquired property in themselves." (ibid, p. 10).

The theorist most closely associated with developing a robust theoretical account of the relationships between property, domination and the state is the anarchist PierreJoseph Proudhon who, while famous for his declaration that "property is theft", is far less well- known for articulating the conceptual connection between slavery and the institution of private property.

Proudhon begins Chapter One of his 1840 text What is Property? as follows:

If I had to answer the following question, "What is slavery?" and if I should respond in one word, "It is murder", my meaning would be understood at once. I should not need a long explanation to show that the power to deprive a man of his thought, his will, and his personality is the power of life and death. So why to this other questions, "What is Property?" should I not answer in the same way, "It is theft", without fearing to be misunderstood, since the second proposition is only a transformation of the first. (Proudhon 2003, p. 1)

Kinna and Pritchard draw on the work of Proudhon and other anarchist theorists to argue that

At the heart of our conceptions of private property and political equality there lies an understanding of dominium that is antithetical to neo-republican conceptions of freedom as non-domination. Private property, by this account, would seem to be the structural manifestation of modern domination rather than a bulwark against it. [...] To understand how it is possible for a worker to contract their labour out to the capitalist, we must first assume that such a thing as possession of oneself and property are natural and obvious. To be a political equal and to be able to alienate 
one's capacity to the state (either in the Hobbesian or Rousseauean formulation), one must understand oneself in the terms established by slavers. (2012, p. 9).

The historical connections between early theories of property and self-ownership and the institution of slavery are reflected in the fact that the Roman idea of dominium meant the absolute right to dispose of a thing as one pleased. This conception resurfaced in European thinking in the mid-seventeenth century, a period that coincided with the colonial expansion of European powers on the back of slavery in Africa.

As Kinna and Pritchard point out, Locke's theory that the mixing of one's labour in a thing constitutes that thing as one's property should perhaps be considered in the context of his position as the secretary to the Lords Proprietors of Carolina from 1668 to 1671, a role that required him to draft constitutions on the keeping of slaves, and his personal investment in and Board membership of the Africa Company, which had an effective monopoly on the slave trade. "In short," as they say, (ibid, p.8) "Locke mixed his labour with the slave trade for over thirty years."

Kinna and Pritchard conclude from their historical analysis that "the conception of selfownership and political subjectivity central to the moral defence of the state is premised on a conception of ownership which is a structural and normative relic of slavery itself." Or, as Gourevitch puts it (2015), "freedom once presupposed slavery"”.

The work of anarchist thinkers like Proudhon, Kropotkin and Bakunin thus offers a clear articulation of a concept of freedom as non-domination that leads logically to the view that the modern state and its underpinning liberal conception of law is "the main vehicle for structural domination" (Kinna and Pritchard, ibid). Proudhon's work also theorises the historical and conceptual connection between the state and the emergence of capitalism. Thus, while there is a debate within anarchist theory about the basis of the anarchist objection to the state (see Jun 2019), focusing on the concept of domination helps to illustrate how the critique of the state and the critique of the capitalist system are intertwined. It also emphasises the distinction between anarchism and liberalism, for as Pritchard explains, "For liberal political society to exist, the alienation of one's property in the self to the state, and to the employer was vital" (Pritchard 2019, p. 74).

The concept of non-domination also plays a significant role in contemporary anarchist thought and activism, where "the word domination today occupies a central place in anarchist political language" [and] "serves as a generic concept for the various systematic features of society whereby groups and persons are controlled, coerced, exploited, humiliated, discriminated against" (Gordon 2008, p. 32). In contemporary anarchism, this criticism is directed not just at the state, but at the interconnected forms of oppression involved in capitalism, patriarchy and white supremacy.

Samuel Clark is another contemporary theorist who has offered a defence of anarchism, and of the possibilities of non-statist societies, centred on non-domination. Clark also discusses slavery, particularly the Atlantic slavery system of the fifteenth-nineteenth century, as "an extreme, institutionalised system of domination" (Clark 2007, p. 106). For Clark, the institution of the state and that of slavery, while not coextensive, are comparable in that both created "huge and unprecedented capacity for elites to dominate others". They are also historically connected, in that "in the world in which modern states operate, the wealth of some and the poverty of others are conditioned by the Atlantic system" (ibid).

While sympathetic to the anarchist analysis of wage-labour as analogous to a form of slavery, Clark acknowledges the problems with this analogy. He notes that the notion of "wage slavery" was often employed in the pro-slavery polemic of defenders of the American South during the American Civil War to make the point that anti-slavery campaigners 
for the North were hypocritical in that "the condition of the 'free workers' they employed was at least as bad as that of Southern slave" (ibid). Yet while it may be true that some critics of capitalism used "slavery" in a purely rhetorical way, the Proudhonian radicals clearly saw the causal and historical connections between slavery and wage-labour; a connection that, perhaps, is echoed in the reference of some contemporary Black activists to "the plantation state". ${ }^{1}$ Clark cautions that in drawing comparisons between the domination of capitalism and that of slavery, it would be false and offensive to the memory of slaves to declare that the domination of wealthy citizens in a liberal democratic state is somehow on a par with that of slaves. Nevertheless, he argues, it would be equally false and offensive to the memories of victims of totalitarian regimes to claim they were better off for being citizens of states rather than slaves. (ibid, p. 107).

Some theorists have argued that "there is something to be said for the idea that anarchists might be republicans who take republican principles far more seriously.[...]. What is baffling for anarchists is how moderate republicans, having uncovered such a radical conception of freedom as non-domination, fail to advocate the kind of radical economic and political changes needed to create a society free from domination." (Leipold 2013).

While some theorists see social anarchism as developing from nineteenth century republicanism, others have emphasised the differences between the two traditions:

The fundamental split between republicanism and anarchism is over the institutional requirements for non-domination. For republicans, interference is rendered not arbitrary - and so does not reduce our freedom - when we are subject to the rule of law. If a state is suitably structured, republicans argue that the law does not restrict our freedom but in fact creates it. (Leipold, ibid).

For anarchists, in contrast, the state "cannot be the solution to domination since it is the state that enforces the mechanisms of violence and control through which the powerful are able to exercise their domination." (ibid, my emphasis).

\section{The Social Conditions of Freedom}

A consideration of the anarchist tradition can add a valuable perspective to recent work on the republican idea of freedom as non-domination and its educational significance. This partly concerns the conceptual understanding of freedom itself. While proponents of the republican idea of freedom as non-domination, as noted above, have argued that this concept transcends the familiar negative/positive dichotomy, this point plays out somewhat differently within the anarchist perspective. For while it is true that on the one hand, anarchism is centrally concerned with defending individuals' freedom from the arbitrary domination of the state and its institutions, this is not to say that there are no positive elements to an anarchist conception of freedom. As Alex Pritchard argues, "the positive incarnation of this is a set of rules and principles, rights and duties that members of a community agree amongst themselves in order to constitute an order that will be the best means for them to realise their vision of the good. In this sense, institutions are central to freedom" (Pritchard 2019, p. 71).

\footnotetext{
${ }^{1}$ I am grateful to Ruth Kinna for drawing my attention to this point.
} 
This emphasis partly explains the importance attached to schools and other educational institutions by anarchist theorists and activists (see Avrich 2006; Haworth 2012; Springer et al. 2016; Suissa 2010). It also suggests some important questions about the extent to which such a conception of freedom can be enacted by, with, or for children, as I will explore below.

Given the rigorous philosophical accounts of freedom developed by anarchist thinkers such as Proudhon, Bakunin and Kropotkin, and their clear educational implications, it is puzzling that this tradition is overlooked by educational theorists focusing on nondomination. Macleod (2015, p. 460), for example, overlooks anarchist theory in claiming that "Many influential approaches to political philosophy do not ground the justification of liberty rights in a general idea of freedom per se" and that republicanism is "distinctive" insofar as it "assigns theoretical primacy to an ideal of freedom itself." Likewise, Snir and Eylon, citing Skinner, claim that the republican conception of freedom as non-domination is unique, "meriting it a place of its own as a political theory" (2016, p. 761). Finally, Hinchliffe claims in his Conclusion (2015, p. 159) to have "traced the genealogy of liberty", but omits any mention of anarchist theory.

A second way in which the anarchist perspective on non-domination can inform educational thinking is through radical experimentation with forms of educational practice outside the state. While in the current context, it is problematic to regard independent, feepaying schools as in any sense challenging the capitalist state or the structural inequalities reinforced by a state education system, it can nevertheless be productive to consider the pedagogical practices within these schools as possible experiments with non-dominating forms of social relationships .

For example, Davina Cooper has explored how the daily lived experience of children and teachers at Summerhill can "create forms of imagining" that unsettle and challenge conventional understandings of property, personal space, and trust. In offering "resources for property's reimagination", (p. 184) such schools make possible "other more critical reversals in how social relations are imagined" (ibid). So while anarchist theorists such as Proudhon, offer a theory of property that allows us to see how dominant liberal conceptions of property are linked historically and conceptually with the capitalist state, the existence of radical democratic educational spaces outside the state system allows children and teachers to explore and imagine, through embodied experience, what such alternative "conceptual life" would look like.

Samuel Clark draws on historical and anthropological accounts of non-statist societies to explore and defend "radical external criticism of current arrangements" (Clark, p. 45). His work is part of a tradition within anarchist thought and practice that, alongside working out a theoretical account of freedom and domination, has sought to explore, develop and enact forms of social organization that will enable people to be free. Alex Pritchard has argued that, notwithstanding anarchists' objection to hierarchies, domination and oppressive social norms, it is misleading to conflate anarchism with "a conception of freedom as a state of unencumbered isolation" (Pritchard 2019, p. 80). Building on the work of Proudhon and other anarchists who emphasised the social conditions of freedom, Pritchard notes the importance of institutionalisation within anarchism, reflected in the long history of anarchist involvement in syndicalism, intentional communities, community organizations and co-ops. (ibid, p. 86). On this account, "freedoms are constituted by the mutual constraints placed upon free agency by our agreed decision-making procedures, while the rules developed collectively and collaboratively shape mutual interactions, and the nature of the decision-making" (p. 83). 
Education presents an interesting set of ideas and tensions, as well as practical examples, in this context. Educational spaces outside the state system, such as radical democratic schools, home schooling communities or informal education projects, can be places where the "radical external criticism" Clark refers to may play out, both through imaginative engagement with political ideas that critique the present and offer a radically different vision of how we can live together, and through the kind of prefigurative practice so central to anarchist theory.

The practical insistence on forms of education that actively resist the capitalist state is an integral element of the anarchist commitment to spontaneous direct action and prefiguration as a form of revolutionary politics. The promotion of direct action is also conceptually connected to the centrality of the idea of freedom as non-domination within anarchism, often translated into a faith in people's capacity to do things for themselves. This strand of anarchism is most closely associated with the British anarchist theorist Colin Ward, who emphasised the value and significance of anarchist-inspired projects such as self-build housing initiatives and educational experiments that acted like "seeds beneath the snow" (Ward 1973) within the capitalist state. The anarchistinspired schools established in the early twentieth century, and as part of the deschooling movement of the 60s and 70's (see Avrich 2006; Kozol 1972; Shotton 1993; Smith 1983; Suissa 2010) were not just a way to challenge the logic of state capitalism and to enact, through prefigurative practice, alternative values of cooperation, freedom and mutual aid, but a form of resistance that prepared people for life in a post-state society. (Morland 2004, p. 26).

If the radical republican understanding of freedom is to inform our educational thought, then, it is worth reflecting on how educational spaces can be radically reconfigured so as to enact non-dominating social relationships. At the same time, the attempt to set up educational environments that reject dominating structures and hierarchies, whether through removing the element of compulsion or enacting more horizontal, collaborative forms of decision-making, raises the same concerns raised by critics of anarchist movements and organizations; namely that, in the absence of formal frameworks and procedures, informal power-groups and elites will develop and pose a threat to individual freedom. These concerns are perhaps heightened when the members of the community are children, echoing Arendt's concerns, articulated forcefully in The Crisis in Education, that

by being emancipated from the authority of adults the child has not been freed but has been subjected to a much more terrifying and truly tyrannical authority, the tyranny of the majority [...] the result is that children have been so to speak banished from the world of grown-ups. They are either thrown back upon themselves or handed over to the tyranny of their own group, against which, because of its numerical superiority, they cannot rebel, with which, because they are children, they cannot reason.... (Arendt 1954, p. 178)

Yet it would be a mistake to assume that anarchist educators advocate a complete removal of pedagogical authority from the educational process, or even that they generally offer a radical challenge to conventional views of adult-child relations. Both historical and contemporary examples of anarchist schools offer illustrations of the attempt to create a community built on anarchist values of equality, freedom and solidarity, alongside a recognition that "the process of growing up free [is not] something passive. It is not a relaxed laissez-faire attitude where children can simply do whatever they want while the educators remain impassive and value free" (Fremeaux and Jordan 2012, p. 108; see also Suissa 2010). 
In considering the educational implications-and tensions-suggested by the radical conception of freedom as non-domination, it is important to look not just at familiar examples of libertarian schools such as Sudbury Valley (see https://sudburyvalley.org/), but at the broader tradition of alternative schools, whether explicitly anarchist or not, that attempted to create a community for adults and children to live together. Such communities, like those created by the Aitkenheads at Kilquhanity School, or Kenneth Barnes at Wennington, embodied something like Paul Goodman's idea of "incidental education," (Goodman 1969) where adult authority derived not from a hierarchical position within an institutional structure determined from outside the community, but from the pedagogical necessity of performing the tasks needed to sustain and nurture the community. (see Barnes 1980; Shotton 1993, pp. 109-116). Children in such communities, far from being "banished from the world of grown-ups", were an organic part of it-learning through everyday social interaction, rather than being isolated from the daily lives of adults in the community by being confined to the institution of the school.

\section{Non-statist Social Imaginaries in Education}

There are two aspects to the incorporation of a non-statist political imaginary into our educational thought and practice. On one level, engaging with the non-statist perspective can add to the critical tools of educational researchers and theorists who see the republican tradition, and particularly the republican concept of freedom, as having the potential to offer a distinctive critical perspective on contemporary educational thought and practice. In failing to turn their critical lens on the state system within which their educational arguments are framed, thinkers like Hinchliffe, Peterson, Snir and Eylon arguably underestimate the danger-a danger clearly stated both by J.S. Mill and by anarchist thinkers such as William Godwin - of granting the state the power to shape children's values and nurture their sense of loyalty. For while republican thinkers have emphasised the importance of nurturing civic virtue in citizens in order for political institutions to be non-dominating, there are, as Leipold argues (ibid), "reasons to be sceptical of this," not least because of "the unlikelihood that civic virtue can be fostered in a system where citizens are excluded from direct participation".

This is not to say that genuinely freedom-enhancing and critical pedagogical processes cannot occur within state school settings. Certainly, Snir and Eylon's work, and the tradition of Critical Pedagogy that they draw on, provides ample evidence to the contrary. Considering the radical republican tradition, however, can expand and enrich our thinking about the possibilities for enhancing freedom through and in education by considering the contingency of the social and political frameworks capable of providing the conditions for freedom.

Taking the anarchist and radical republican tradition seriously would demand a critical engagement with the statist assumptions in the work of political philosophers and philosophers of education, questioning whether the state itself can really offer the best framework for enabling non-dominating social relationships.

Most philosophers of education, like most political philosophers, assume rather than arguing for the state. Macleod, for example, assumes the state as given in arguing that "promoting freedom as non-domination requires ensuring that citizens are not subject to arbitrary exercises of power by the state or by fellow citizens.”(MacLeod 2015, p. 461). Indeed, it is not just the state, but the capitalist state, that is assumed in his mention of 
"preparation for participation in the economy" as one of the main purposes of schools (p. 158) and his reference to "arbitrary differences between children, such as their place in the class system" (p. 459).

Yet in regarding the class system as a permanent feature of our social and political reality, rather than as an objectionable structural aspect of the capitalist state-one of the institutions that the very conception of freedom as non-domination has the potential to challenge-Macleod fails to consider the possible tensions between this conception and his own statist assumptions.

Similarly, Hinchliffe, in discussing the republican example of slavery as the paradigmatic case of domination, notes that "we are not dominated most of our lives and so the comparison with slavery is inflated" $(2015$, p. 31$)$. Yet a serious engagement with anarchist arguments about the connections between conceptual understanding and historical reality of slavery were linked, within radical movements and theory, to the establishment of the capitalist state, would add an important dimension to this discussion.

Not only is the concept of the state, much less any critique of it, entirely absent in Hinchliffe's book; remarkably, it is actually erased from his discussion of J.S. Mill's famous argument against state schooling. Hinchliffe says "Mill himself was of the firm view that education, just by its nature, encouraged uniformity and so was inherently illiberal, but the context makes clear that by 'education' he in fact means 'schooling;"' (2015, p. 69). This is a significant and telling distortion. In fact, what Mill says is:

A general state education is a mere contrivance for moulding people to be exactly like one another, and as the mould in which it casts them is that which pleases the dominant power in the government [...]. (1869, p. 164).

It is not education, or even schooling, that Mill sees as the problem. He was not an advocate of children's rights like A.S. Neill or a libertarian like Illich; his objection was to the idea of the state controlling children's education.

Later in the book, Hinchliffe enlists Gramsci to support his argument for freedom in education. Yet although Gramsci was, as Levy (2012) has shown, wary of the uncritical adoption of state socialism by Marxist theorists and activists, the concept of hegemony, as Day (2005) has argued, is itself linked to a logic of statist thinking. Day offers an anarchist critique of what he calls "the hegemony of hegemony", i.e. the idea that "effective social change can only be achieved simultaneously and en masse, across an entire national and supra-national space" and argues that Gramsci, with Lenin, "theorised hegemony primarily as a mode of political revolution totalising in its intent and reliant upon an authoritarian and state-centred model of social change ultimately of use only to those who seek power over others" (in Kinna 2014, p. 225).

In effect, by failing to even mention the state-by referring constantly to "schooling" rather than "state schooling" throughout their analysis, for example - these theorists render it invisible and therefore beyond critique.

Snir and Eylon explicitly link their discussion of non-domination in education to Critical Pedagogy which, as they say, is founded on a critique of existing socio-political reality. Critical Pedagogy and civic republicanism are connected, they argue, in that they "not only reject traditional liberalism, but are explicitly opposed to the growing trend of neoliberalism, conservatism and authoritarianism" (Giroux, in Snir and Eylon 2016, p. 760). However, while they acknowledge the work of theorists such as Foucault and Illich who analyse the school "as a site of domination, surveillance, and lack of freedom", and argue that "contemporary republican theory is not sensitive enough to various kinds of relations of domination that often exist within school" (ibid p. 764), they do not reflect on the statist 
assumptions behind their analysis. When referring to "schools" throughout their argument, like most other theorists in the field, actually mean—but never say_-"state schools".

An engagement with the radical republican and anarchist tradition would prompt the important question of whether such relations of domination are inevitable features of schools, conceived of as sites for intentional adult intervention in children's development, or whether they are actually reflective of the relations of domination that characterise the capitalist state. Is the problem, in other words, with schools as such, or is it with particular kinds of state schooling?

While some anarchists are sympathetic to libertarian educational ideas and practices, the emphasis on the need to nurture substantive values such as cooperation and mutual aid, alongside the conception of freedom as "constituted by the mutual constraints placed upon free agency by our agreed decision making procedures" (Pritchard 2019, p. 83) means that most anarchists share a suspicion of a laissez faire attitude to children's development and of the idea of a politically "neutral" education.

Snir and Eylon argue for greater student involvement in the daily decision-making within schools, which they see as reflecting the republican approach to the theory of deliberative democracy developed by theorists such as Dryzek and Gutmann and Thompson. However, they claim that existing theories of deliberative education "focus on preparing students to take part in future deliberative processes, as adult citizens" and "rarely view such discussions as an inherent aspect of decision-making in the present, behind school gates." As a result, they argue, students "are in fact dominated". (2016, p. 766).

Yet the history of radical democratic education furnishes countless rich examples of schools where students have plenty of "effective control over the power exercised in school", and are genuinely free to make their own decisions about how and what to learn. Schools such as Summerhill offer a radical reconception of what it means to extend such freedom to children. As Davina Cooper comments, reflecting on Summerhill's 2000 appeal against Ofsted to the Independent Schools Tribunal, "There really is something extraordinary about this case in which High Court Proceedings are stopped and government officials are forced to wait, while a meeting of children decide whether or not to accept their proposals." (Appleton, in Cooper 2014, p. 176).

In defending the idea that school pupils should have greater control over the power exercised in schools, Snir and Eylon (2016, p. 766) comment that "if students are allowed to contest everything that takes place at school as they please, the entire school system would be undermined." (ibid, p. 768). Yet this comment reflects not just the statist assumptions behind their view, but a failure to imagine very different ways of thinking about what "contestation" means and what an educational environment fully committed to implementing a radical conception of democracy would look like. For as a Summerhill pupil quoted by David Gribble remarks, "There are hardly any rebels at Summerhill because there is nothing to rebel against except the School Meetings, and in my opinion the school meeting is totally sensible." (Gribble 1998, p. 61).

In a later paper, Snir and Eylon focus on how the republican conception of freedom as non-domination can help us think about social justice in education. They see Pettit's analysis of how "significant social inequalities necessarily put some people in a position of domination in relation to others" as supporting an argument against the privatization of education. (Snir and Eylon 2017, p. 590). As Peterson rightly points out (2017, p. 172), the republican approach leads to a broader understanding of justice than the distributive sense of social justice central to Rawlsian liberal theory. However because they fail to address, much less question, the inherent statist assumption in their thinking about education, freedom and equality, these theories of educational justice end up taking the form of 
a distributive model whereby the state is responsible for the just distribution of educational opportunities.

In his recent paper on this issue, Peterson develops Snir and Eylon's critique of private education to argue, drawing on the republican view of freedom as non-domination, that "inequitable systems of public education present a concern at least as important for social justice as debates concerning private education.” (ibid). Drawing on Pettit's (2012, p. 77) account of republican social justice as requiring "that people should enjoy freedom as nondomination in their relationships with one another, whether as individuals to individuals, as groups to groups, or as groups to individuals", Peterson makes a compelling argument to the effect that the existence of grammar schools in England violates the requirements of social justice, in that it allows the power and interests of one group of citizens to arbitrarily dominate the interests of others. (Peterson 2017, p. 173).

Peterson, unlike Snir and Eylon, is explicit in his assumption that the state, and state schooling, is the background framework for all such debates. Indeed he echoes the republican view of the state as the guarantor of freedom in stating that republican social justice requires the state to act to disrupt the inequality created by grammar schools and similar models of selective schooling. Hopkins (2015, p. 617) adopts a similar set of assumptions in endorsing Pettit's justification for coercive measures undertaken by the democratic state given the ability of citizens to contest state actions - in this case, to contest the content of the school curriculum and standards.

However if one considers the ways in which the state, and particularly the capitalist state, is itself structured on and by relations of domination, debates about education justice-indeed, the very coherence of any definition of "educational" justice as distinct from the justice of social and political arrangements-look rather different.

Of course theorists such as those discussed here may have well-worked out arguments against anarchism and other radical political positions. They do, however, see the republican tradition, and particularly the republican concept of freedom, as having the potential to offer a distinctive critical perspective on contemporary educational thought and practice. The point I want to emphasise is that, to the extent that they accept, with Pettit, that a democratic state with constitutional checks and balances on its institutions can create and protect human freedom then, as Leipold (2013) points out, "If this is all that republicanism has to offer then it becomes barely distinguishable from existing liberal democracies."

Beyond an exercise in political philosophy, though, is there a sense in which non-statist ideas can or should figure in educational practice?

A further way in which the radical republican, and particularly the anarchist, tradition, can contribute to critical philosophical work on education that is concerned with enhancing human freedom is to expand our political imagination so as to include imagining the possibility of a stateless society. At a time when, according to UN estimates, the number of international migrants is over 250 million and could rise to 400 million by 2050 (see IOM 2010), several political theorists have argued that 'post-Wetsphalian' conceptions of sovereignty, democratic politics and the public sphere "are ineffective if they do not also address the normative regulation of peoples' movement across territorial boundaries" (Benhabib 2004 , p. 3) and that we need new normative models of political organization in a world where, as Benhabib puts it, "The old political structures may have waned but the new political forms of globalization are not yet in sight." (ibid).

The tradition of anarchist thought can offer a rich vein of thinking about the kinds of political structures and practices that can enable the flourishing of human freedom and equality in a world structured by mass displacement and migration. Both philosophers and migration theorists have defended the need for political theory to "alter its foundational 
presuppositions," (Nail 2015b) and called for radical, utopian thinking (see Cohen and Van Hear 2017, p. 494) to address and theorise the central issue of "the figure of the migrant" (Nail 2015a).

One aspect of the idea of nonstatist political imaginaries concerns the possible value, as part of children's educational encounters with political ideas, of imagining a world without states and without borders. In today's world, the urgent educational and political questions are perhaps not best addressed by a framework of citizenship education, but by a form of political education that asks, amongst other things, whether it is possible to envisage political structures that do not constitute themselves in terms of citizenship as a status of belonging to a sedentary and territorially bounded political community.

Concerned readers may worry that in the current climate, the last thing we need to be promoting in schools is a willingness to question the framework of the liberal democratic state. But my suggestion for a far more open-ended and critical form of "political education" than current models of citizenship education is not a call to abandon the educational project of ensuring that children understand the workings of our current political systems and the democratic values that underpin them. It is, however, a call to allow space within such projects for asking what positive values-cooperation, equality, and non-domination, for example - these institutions are designed to guarantee and whether or not they are the best way to do so.

\section{Conclusion}

The statist assumptions of most philosophers and theorists of education go hand in hand with a focus on schools, particularly state schools, as the primary site for thinking about education. Expanding our critical gaze to include the political frameworks within which education is provided and defined will also broaden our discussions of education to include spaces and processes beyond those of formal schooling, such as informal educational settings, the pedagogical aspects of social movements, and community organizing.

If the aspiration is to challenge all forms of domination and to imagine and pursue a different political organization based on non-domination, the question becomes not whether or not the existence of private schools enhances or inhibits the just distribution of educational goods, but whether or not a space can exist, within any educational sites, where alternative political forms can be enacted and imagined. Thus the non-statist political imaginary I have defended here can offer a different lens through which to theorise issues of equality, justice and freedom in education from that of the public/private dichotomy that often characterises mainstream educational theory and research.

Pedagogical relationships within schools or other spaces can be seen-as they are for many anarchist educators (see Avrich 2006; Gribble 1998; Haworth 2012; Kozol 1972; Shotton 1993; Smith 1983; Springer et al. 2016; Suissa 2010)_as ways of prefiguring alternatives to current political institutions and creating spaces for imagining a different, freer, human society. Such radical challenges can certainly take place within state schools - although in the current climate of the "anti-radicalization" agenda in schools, this may be increasingly difficult (see Sukarieh and Tannock 2016). In urging philosophers of education to engage seriously with radical and anarchist traditions, then, I am not claiming that the state and all its institutions are always the enemy of freedom. I am, however, suggesting that we need to turn our critical lens on the claims of republican theorists that the state, and state schooling, can be the best guarantor of freedom. 
Combining an openness to the possibility of non-statist forms of political life, alongside a radical conception of freedom as non-domination that acknowledges the social conditions of freedom and the point that, as Pritchard notes, "for the majority of anarchists, you can only be free in conjunction with others" ( $p$ 72), can shift our attention to questions of what kinds of educational practices, whether inside or outside the state system, can nurture and enhance non-dominating relations. Michael Fielding offers a concrete example of such educational practice in his exploration of the work of Alex Bloom and other radical state educators. Bloom's project, reflected in the ethos, curriculum and structure of St George in the East, is underpinned, Fielding argues, by a view of human flourishing similar to that found in the social anarchist tradition. Through creating a school run "on the basis of dialogic engagement and communal restitution", (Fielding 2014, p. 89), Bloom demonstrated "both the practical possibility and the deep desirability of "the school as an experimental and continually reorganized order of relationships' (Small 1968)" (ibid, p. 88).

Philosophers of education who focus on concepts like non-domination as part of developing a critical perspective on contemporary educational policy and practice often ignore both the history of these concepts within radical traditions and the history of educational experiments associated with these traditions. If the concept of non-domination is to do the work we want it to do in helping us to challenge and dismantle unjust social and political structures and relations in the name of something better, then, I have suggested, the radical republican and anarchist traditions have much to offer in creating a conceptual and pedagogical "space to imagine things differently".(Bottici 2014).

Acknowledgements I would like to thank Yuval Eylon, Geoffrey Hinchliffe, Ruth Kinna, Stuart Tannock, Patricia White and two anonymous reviewers of this journal for their helpful comments on an earlier draft of this paper.

Open Access This article is distributed under the terms of the Creative Commons Attribution 4.0 International License (http://creativecommons.org/licenses/by/4.0/), which permits unrestricted use, distribution, and reproduction in any medium, provided you give appropriate credit to the original author(s) and the source, provide a link to the Creative Commons license, and indicate if changes were made.

\section{References}

Arendt, H. 1954. The Crisis in Education. In Between Past and Future. New York: Penguin.

Avrich, P. 2006. The Modern School Movement: Anarchism and Education in the United States. Oakland: AK Press.

Barnes, K. 1980. Energy Unbound-The Story of Wennington School. York: William Sessions Ltd.

Bellamy, R. 2002. Being Liberal with Republicanism's Radical Heritage. Res Publica 8(3): 269-274.

Benhabib, S. 2004. The Rights of Others. Aliens, Residents and Citizens. Paper Presented at Conference on "Migrants, Nations and Citizenship, CRASSH, 5-7 July 2004 (reproduced with the author's permission).

Bottici, C. 2014. Imaginal Politics: Images Beyond Imagination and the Imaginary. New York: Columbia University Press.

Clark, S. 2007. Living Without Domination: The Possibility of an Anarchist Utopia. Abingdon: Routledge.

Cohen, R., and N. Van Hear. 2017. Visions of Refugia: Territorial and Transnational Solutions to Mass Displacement. Planning Theory \& Practice 18(3): 494-504.

Cooper, D. 2014. Everyday Utopias: The Conceptual Life of Promising Spaces. Durham: Duke University Press.

Day, R.J.F. 2005. Gramsci is Dead: Anarchist Currents in the Newest Social Movements. London: Pluto Press.

Edmonds, D., and N. Warburton. 2010. Philosophy Bites. Oxford: Oxford University Press.

Fielding, M. 2014. 'Bringing Freedom to Education': Colin Ward, Alex Bloom and the Possibility of Radical Democratic Schools. In Education, Childhood and Anarchism: Talking Colin Ward, ed. Catherine Burke and Ken Jones. Abingdon: Routledge.

Fremeaux, I., and J. Jordan. 2012. Anarchist Pedagogy in Action: Paideia, Escuela Libre. In Anarchist Pedagogies, ed. R.H. Haworth. Oakland: PM Press. 
Goodman, P. 1969. The Present Moment in Education. New York Review of Books, April 10.

Gordon, U. 2008. Anarchy Alive!. London: Pluto Press.

Gourevitch, A. 2012. An Iron Chain of Bondage: Lessons from the Knights of Labor. Open Democracy, November 29.

Gourevitch, A. 2013a. Labour Republicanism and the Transformation of Work. Political Theory 41(4): 591-617.

Gourevitch, A. 2013b. Wage-Slavery and Republican Liberty. Jacobin, February 28.

Gourevitch, A. 2015. From Slavery to the Cooperative Commonwealth. Cambridge: Cambridge University Press.

Gribble, D. 1998. Real Education: Varieties of Freedom. London: LibEd.

Haworth, R. (ed.). 2012. Anarchist Pedagogies: Collective Actions, Theories and Critical Reflections on Education. Oakland: PM Press.

Hinchliffe, G. 2013. Review of Civic Republicanism and Civic Education: The Education of Citizens by Andrew Peterson. Journal of Philosophy of Education 47(1): 147-150.

Hinchliffe, G. 2015. Liberty and Education: A Civic Republican Approach. Abingdon: Routledge.

Hopkins, N. 2015. Freedom as Non-Domination, Standards and the Negotiated Curriculum. Journal of Philosophy of Education 49(4): 607-618.

Jun, N. 2019. The State. In The Palgrave Handbook of Anarchism, ed. Carl Levy and Saul Newman. Switzerland: Cham.

Kinna, R. (ed.). 2014. The Bloomsbury Companion to Anarchism. London: Bloomsbury.

Kinna, R., and A. Pritchard. 2012. Anarchism and Non-Domination. Paper Presented at the 2nd International Conference of the Anarchist Studies Network. Loughborough University.

Kozol, J. 1972. Free Schools. Boston: Houghton Mifflin.

Leipold, B. 2013. Anarchists and Republicans: Bedfellows? In Open Democracy. https://www.opendemocracy. net/ourkingdom/bruno-leipold/anarchists-and-republicans-bedfellows? Accessed 29 Nov 17.

Leipold, B. 2016. What can Republicanism Offer the Left? In The Oxford University Politics Blogs. https://blog. politics.ox.ac.uk/what-can-republicanism-offer-the-left/. Accessed 10 Apr 2019.

Levy, C. 2012. Gramsci and Anarchism. In Libertarian Socialism: Politics in Black and Red, ed. A. Pritchard et al. London: Palgrave Macmillan.

Macleod, C. 2015. Freedom as Non-domination and Educational Justice. Critical Review of International Social and Political Philosophy 18(4): 456-469.

Morland, D. 2004. Anti-Capitalism and Poststructuralist Anarchism. In Changing Anarchism: Anarchist Theory and Practice in a Global Age, ed. J. Purkis and J. Bowen. Manchester: Manchester University Press.

Nail, T. 2015a. The Figure of the Migrant. Stanford: Stanford University Press.

Nail, T. 2015b. The Figure of the Migrant: An Interview with Thomas Nail. Critical Theory. http://www.criti cal-theory.com/the-figure-of-the-migrant-an-interview-with-thomas-nail/. Accessed $10 \mathrm{Apr} 2019$.

Peterson, A. 2011. Civic Republicanism and Civic Education. Basingstoke: Palgrave MacMillan.

Peterson, A. 2017. Civic Republican Social Justice and the Case of State Grammar Schools in England. Studies in Philosophy and Education 37(2): 167-179.

Pettit, Phillip. 1997. Republicanism: A Theory of Freedom and Government. Oxford: Clarendon Press.

Pettit, P. 2011. The Instability of Freedom as Noninterference: The Case of Isaiah Berlin. Ethics 121(4): 693-716.

Pettit, Philip. 2012. On the People's Terms: A Republican Theory and Model of Democracy. Cambridge: Cambridge University Press.

Pritchard, A. 2019. Freedom. In The Palgrave Handbook of Anarchism, ed. Carl Levy and Saul Newman. Cham: Palgrave Macmillan.

Proudhon, P.-J. 2003. [1840] What Is Property? Or, An Inquiry into the Principle of Right and of Government. IndyPublish.

Rousseau, J.-J. 1920. [1792] The Social Contract (trans: Cole, G.D.H.) Amherst, NY: Prometheus Books.

Shotton, J. 1993. No Master High or Low: Libertarian Education and Schooling in Britain, 1890-1990. London: LibEd.

Skinner, Q. 2008. Freedom as the Absence of Arbitrary Power. In Republicanism and Political Theory, ed. C. Laborde and J. Maynor. Oxford: Blackwell.

Small, M. 1968. About Risinghill. Anarchy 92 8(10): 289-306.

Smith, M. 1983. The Libertarians and Education. London: George Allen and Unwin.

Snir, I., and Y. Eylon. 2016. Pedagogy of Non-domination: Neo-republican Political Theory and Critical Education. Policy Futures in Education 14(6): 759-774.

Snir, I., and Y. Eylon. 2017. Civic Republicanism and Education: Democracy and Social Justice in School. Studies in Philosophy and Education 36(5): 585-600. 
Springer, S., et al. (eds.). 2016. The Radicalization of Pedagogy: Anarchism, Geography, and the Spirit of Revolt. Lanham: Rowman and Littlefield.

Suissa, J. 2010. Anarchism and Education: A Philosophical Perspective. New York: PM Press.

Sukarieh, M., and S. Tannock. 2016. The Deradicalisation of Education: Terror, Youth and the Assault on Learning. Race and Class 57(4): 22-38.

Ward, C. 1973. Anarchy in Action. London: Freedom Press.

Publisher's Note Springer Nature remains neutral with regard to jurisdictional claims in published maps and institutional affiliations. 